\title{
The Role of Iron Metabolism in Lung Inflammation and Injury
}

Jonghan Kim and Marianne Wessling-Resnick*

Department of Genetics and Complex Diseases, Harvard School of Public Health, Boston, MA 02115, USA

\begin{abstract}
Iron is required for many vital functions including oxygen transport and energy metabolism. Protective mechanisms maintain optimal iron concentration involving dynamic regulation of the transporters and iron storage proteins. In addition to these systemic regulatory mechanisms, the unique lung environment must provide detoxification from metal-induced oxidative stress and pathogenic infections. This review focuses on the unique role of iron metabolism in lung injury and inflammation.
\end{abstract}

Keywords: Iron status; Oxidative stress; Metal exposure; Inhalation; Bronchoalveolar lavage

Abbreviations: ARDS: Acute Respiratory Distress Syndrome; BAL: Bronchoalveolar Lavage; Dcytb: Duodenal cytochrome b; DMT1: Divalent Metal Transporter 1; FPN: Ferroportin; Lf: Lactoferrin; LfR: Lactoferrin Receptor; Nramp1: Natural Resistance-associated Macrophage Protein 1; PAP: Pulmonary Alveolar Proteinosis; RBC: Red Blood Cells; Tf: Transferrin; TfR: Transferrin Receptor

\section{Introduction}

Iron is required for many vital functions including oxygen transport and energy metabolism. About $3 / 4$ of total body iron is present in heme associated with hemoglobin, myoglobin and cytochromes, while nonheme iron is either stored in tissues or transported in the circulation bound to the serum protein transferrin [1]. Low body iron status results in iron-deficient anemia, impaired motor activity and poor brain development [2-5]. On the other hand, high iron stores promote oxidative stress triggering inflammatory responses and cellular injury that eventually leads to cell damage and death. The body has therefore developed protective mechanisms to maintain optimal iron concentration. Protective feedback includes dynamic regulation of the expression of transporters and proteins for iron storage. In addition to these systemic regulatory mechanisms, the unique lung environment must provide detoxification from metal-induced oxidative stress and pathogenic infections. Comprehensive reviews about the molecular mechanisms of iron regulation are available [6-8], therefore we will restrict our focus to the role of iron metabolism in lung injury and inflammation

\section{Overview of Iron Metabolism in the Body}

The serum concentration of iron at steady-state is closely governed by absorption and clearance of iron. Both heme and non-heme forms of iron are absorbed from the gut, but through different transport mechanisms. Non-heme iron import begins with the reduction of ferric iron $\left(\mathrm{Fe}^{3+}\right)$ by duodenal cytochrome $\mathrm{b}$ (Dcytb) protein to ferrous iron $\left(\mathrm{Fe}^{2+}\right)$, which is then taken up by divalent metal transporter 1 (DMT1) at the duodenal apical membrane into the cytosol [9-11]. Less is known about the import of dietary heme, although candidate transporters have emerged $[12,13]$. Upon entering the intestinal enterocyte, intracellular iron can be incorporated in ferritin for storage or exported across the basolateral surface into circulation by ferroportin (FPN) [14,15]. FPN is assisted by hephaestin, a membrane-bound ferroxidase that converts $\mathrm{Fe}^{2+}$ to $\mathrm{Fe}^{3+}$ to promote iron binding to transferrin for its delivery to peripheral tissues [16].

Transferrin (Tf) delivers iron to erythroid cells where DMT1 appears also to be essential for iron acquisition necessary for heme production $[9,17]$. Red blood cells contain the most abundant pool of iron in the body in the hemoglobin complex. After destruction of senescent erythrocytes, non-heme iron is stored within macrophages or returns to the circulation where iron is recycled for another round of erythropoiesis. There is no known pathway for iron excretion. Excess iron is stored in the liver and other parenchymal cells, typically in the ferritin-associated form. Since iron is efficiently conserved, body iron stores are mainly controlled by regulation of iron absorption $[6,18]$.

The absorption of iron is regulated transcriptionally, posttranscriptionally and post-translationally. The two major iron transporters, DMT1 and FPN, are negatively regulated by body iron status at the transcriptional level $[19,20]$. FPN transcripts and several DMT1 splice variants also contain Iron-Responsive Elements (IREs) that confer post-transcriptional regulation by Iron-Responsive Proteins (IRPs). In addition, the liver senses iron status through a series of molecular events to promote the release of hepcidin into the blood. Hepcidin is a 25 -amino acid polypeptide hormone and plays a central role in iron homeostasis by responding not only to the body iron status but also to inflammation and hypoxia. Hence, the body iron level and plasma hepcidin concentration are positively related [21,22]. Hepcidin binds to FPN and facilitates its degradation, thereby reducing iron absorption [23]. Recent evidence hints at hepcidin regulation of DMT1 by a degradative pathway as well [24]. Evolution has presumably found two pathways to protect the body from iron toxicity: a) regulation of absorption by controlling transporters via hepcidin and b) storage to detoxify excess iron by sequestering in a less reactive form.

\section{Iron homeostasis in the lung}

In the lung, iron distributes in both extracellular and intracellular fluids. After intratracheal instillation of ${ }^{59} \mathrm{Fe}$ in rats, radioisotope is found largely in lung tissues (54\%) with remaining metal associated with bronchoalveolar lavage (BAL) protein as bound $(22 \%)$ and

*Corresponding author: Marianne Wessling-Resnick, Harvard School of Public Health, Department of Genetics and Complex Diseases, 665 Huntington Avenue, Boston, MA 02115, USA, Tel: 617-432-3267; Fax: 617-432-5236; E-mail: wessling@hsph.harvard.edu

Received November 18, 2011; Accepted January 21, 2012; Published January 25, 2012

Citation: Kim J, Wessling-Resnick M (2012) The Role of Iron Metabolism in Lung Inflammation and Injury. J Aller Ther S4:004 doi:10.4172/2155-6121.S4-004

Copyright: (c) 2012 Singleton PA, et al. This is an open-access article distributed under the terms of the Creative Commons Attribution License, which permits unrestricted use, distribution, and reproduction in any medium, provided the original author and source are credited. 
unbound (5\%) forms [25]. BAL cell pellets (1\%) also contain iron, but this value might be underestimated because the recovery of BAL cells depends on the efficiency of lavage. Notably, systemic iron-deficiency with low serum and liver iron concentrations does not seem to affect lung iron levels [26], whereas iron overload is associated with high iron levels in the lung [27]. In addition, pulmonary epithelial lining fluids contain a variety of antioxidant molecules, including mucin, ascorbate, reduced glutathione and other proteins, which not only protect the lungs from oxidative stress [28], but also alter iron's redox potential and bioavailability.

Lung epithelial cells express a variety of iron-associated molecules that serve specific functions (Table 1). These include transferrin (Tf) and its receptor (TfR), lactoferrin (Lf) and its receptor (LfR), ferritin, DMT1 and FPN. Macrophages express natural resistance-associated macrophage protein-1 (Nramp1) as well as most of the molecules that are expressed in the epithelial cells, while neutrophils participate in iron homeostasis by releasing several cell-specific modulators, including Lf, superoxide anion $\left(\mathrm{O}_{2}^{-}\right)$and siderocalin. Pulmonary uptake of airborne particulate matter accounts for ingestion of $10 \mu \mathrm{g}$ iron every day $[29,30]$. Although inhalation is not a major pathway of iron acquisition, continuous exposure to elevated levels of iron may result in greater risk of metal-related toxicity. Multiple cells participate in lung iron homeostasis, as reviewed in reference [38]. Figure 1 focuses on airway epithelium and diagrams the functions of iron-associated molecules listed in Table 1. Their functions are detailed below.

\section{Lung iron metabolism and infection}

Iron metabolism is intrinsically linked to innate immunity by regulation of iron availability to pathogens. Infection and inflammation lead to lung injury. A considerable body of epidemiological evidence indicates that iron stores are associated with disease susceptibility and inflammatory responses. High iron status is related to many infectious diseases and inflammatory responses, as exemplified by malaria, viral infection and neurodegeneration. Detailed information about iron and systemic infection-inflammation can be found in several recent reviews [8,31]. For example, iron administration is known to increase mycobacterial growth [32,33], resulting in increased morbidity and

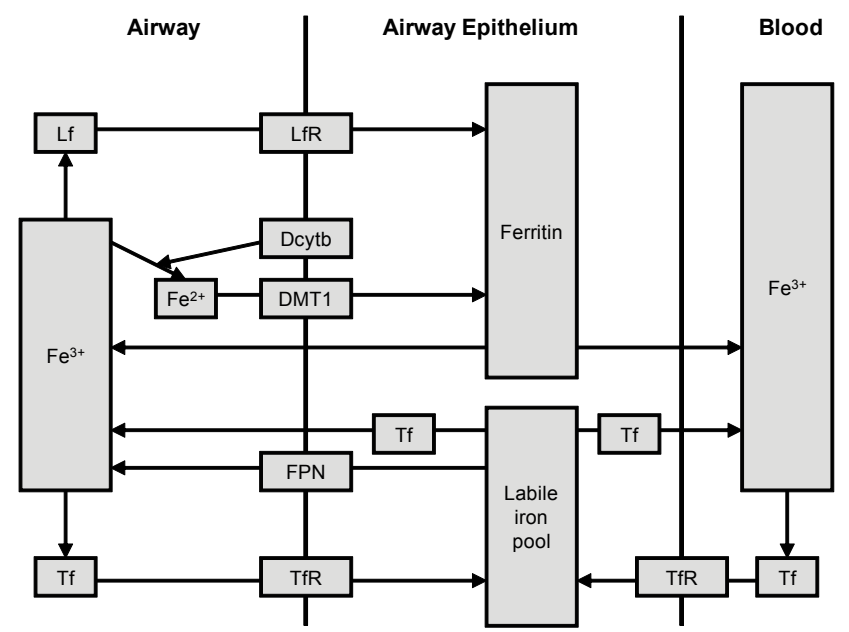

Figure 1: Iron homeostasis in the lung epithelium

Shown is a model of iron transport and homeostasis. Abbreviations used: Dcytb: Duodenal cytochrome b; DMT1: Divalent Metal Transporter 1; FPN: Ferroportin; Lf: Lactoferrin; LfR: Lactoferrin receptor; Tf: Transferrin; TfR: Transferrin receptor.

\begin{tabular}{|c|c|c|}
\hline Molecules & $\begin{array}{l}\text { Known or proposed } \\
\text { functions }\end{array}$ & Lung cell type \\
\hline $\begin{array}{l}\text { Transferrin and its } \\
\text { receptor }\end{array}$ & $\begin{array}{l}\text { Import and export iron } \\
\text { between airways or blood }\end{array}$ & Epithelial, Macrophage \\
\hline $\begin{array}{l}\text { Lactoferrin and its } \\
\text { receptor }\end{array}$ & Import iron from the airway & $\begin{array}{l}\text { Epithelial, Macrophage, } \\
\text { Neutrophil }\end{array}$ \\
\hline DMT1 & Import iron into the cell & Epithelial, Macrophage \\
\hline Nramp1 & $\begin{array}{l}\text { Import iron into the } \\
\text { macrophage }\end{array}$ & Macrophage \\
\hline Duodenal cytochrome b & $\begin{array}{l}\text { Convert } \mathrm{Fe}^{3+} \text { to } \mathrm{Fe}^{2+} \text { at } \\
\text { the apical membrane of } \\
\text { epithelial cells }\end{array}$ & Epithelial \\
\hline Ferritin & $\begin{array}{l}\text { Store iron inside the cell; } \\
\text { transport iron out of the cell }\end{array}$ & Epithelial, Macrophage \\
\hline Siderocalin & $\begin{array}{l}\text { Binds iron in a complex with } \\
\text { endogenous catechol or } \\
\text { siderophores secreted by } \\
\text { invading pathogens }\end{array}$ & Epiethelial, Neutrophil \\
\hline Hepcidin & $\begin{array}{l}\text { Hormone regulating } \\
\text { systemic iron metabolism } \\
\text { that may exert local control } \\
\text { in the lung }\end{array}$ & Epithelial \\
\hline Ferroportin & $\begin{array}{l}\text { Efflux intracellular iron to } \\
\text { the airway }\end{array}$ & Epithelial, Macrophage \\
\hline
\end{tabular}

Table 1: Characteristics of molecules that are involved in pulmonary iron homeostasis.

mortality $[34,35]$ and dietary iron is associated with occurrence and death from tuberculosis [36]. On the other hand, iron deficiency appears to provide a protective mechanism from infection by limiting iron utilization [37] and by improving the inflammatory condition [8].

Among the factors listed in Table 1, lung Tf not only imports iron from the airway into the epithelial cells but it also is involved in iron transport from the intracellular space to the outside of the cell, either blood or the airway. Unlike serum levels, pulmonary Tf is unchanged upon iron exposure [25]. Transcripts for its receptor are detected in bronchial epithelium, type II alveolar cells, macrophages and bronchus-associated lymphoid tissue. Since Tf expression is not influenced by systemic iron overload, a local regulation of Tf-TfR expression is postulated [25]. The expression of TfR diminishes in response to inflammation, efficiently depleting iron required for the growth of pathogens such as L. pneumophila, M. tuberculosis and $M$. avium [39-42]. Lf is another lung iron binding protein found in most surface secretions that also modifies iron availability. Airway iron binds to Lf and is taken up by LfR present in the lung epithelial cells and macrophages, followed by the storage of iron in ferritin. Lung infection appears to induce Lf release through inflammatory cytokines [31]. However, while exogenous Lf ameliorates pulmonary M. tuberculosis in a mouse model of iron overload [43] and opportunistic P. aeruginosa infection in patients with cystic fibrosis [44,45], Lf knock-out mice do not exhibit increased susceptibility to these pathogens [46].

Nramp1 has a more defined role in innate immunity as the name "natural resistance" implies. Nramp1 is a divalent metal transporter in phagosomes and reduces phagosomal iron [47] in a pH-dependent fashion and confers resistance to intraphagosomal parasites $[47,48]$ Infection also increases the expression of Nrampl and Nramp1 knockout mice are more vulnerable to infection [49]. Nramp1 is also involved in suppression of IL-10 expression by iron mobilization, resulting in elevated iNOS production by macrophages, which restricts microbial growth [50-52].

While Tf significantly contributes to iron transport across the lung epithelium, non-Tf bound iron (NTBI) can also enter the cell 
through the action of DMT1. DMT1 (also known as Nramp2) is a closely related homolog expressed in the lung $[26,53,54]$. In rat lungs, DMT1 protein is predominantly found in normal airway and alveolar epithelium, especially type II cells [53], while DMT1 transcripts are also found in bronchus-associate lymphoid tissue adjacent to large airways [53]. Unlike intestinal DMT1, lung DMT1 mRNA does not appear to be highly regulated by iron status $[27,53,55]$. As a consequence, pulmonary iron absorption is not always correlated with lung iron status [53]. For example, Dcytb, which is found in airway epithelial cells and functions as a ferrireductase to support DMT1 function, is elevated by iron exposure [56]. Furthermore, exposure of the lungs to iron oxide particles can promote up-regulation of DMT1 mRNA in alveolar macrophages and nearby epithelial cells [53]. Hence, DMT1 expression may be more directly altered by extracellular iron levels in the lung rather than by changes in intracellular or systemic iron levels. In addition, proinflammatory cytokines, such as TNF- $\alpha$ and interferon- $\gamma$, as well as inorganic fiber like asbestos, promote DMT1 up-regulation in bronchial epithelial cells $[57,58]$. These data suggest that DMT1 contributes to uptake and detoxification of iron through regulation of non-IRE mRNA isoforms in the lung [57,59]. Indeed, Belgrade rats with DMT1 deficiency display increased pulmonary inflammation in the resting state [60]. Lung inflammation mediated by intratracheal instillation of lipopolysaccharide in Belgrade rats is greater than control rats [60]. Taken together, these observations indicate DMT1 functions to provide a protective barrier from toxic environmental stimuli resulting from airborne metals [59-61].

The hepcidin-FPN axis of regulation provides a more direct link between cellular iron availability and inflammation. This ironresponsive peptide depletes circulating iron by inhibiting FPN function such that iron is unavailable to extracellular pathogens. While high serum iron appears to be associated with several microbial infections [62], reduced cellular iron levels found in hemochromatosis appear to provide resistance to infection, particularly intracellular pathogens. For example, $M$. tuberculosis growth and iron acquisition is significantly impaired in iron-depleted macrophages isolated from patients with HFE-associated hemochromatosis [63]. This mechanism is further supported by other models wherein FPN over-expression leads to impaired growth of intracellular pathogens with the addition of hepcidin enhancing their growth except in cells expressing mutant FPN $[64,65]$. Hence hepcidin plays an important role in pulmonary inflammation through its regulation of iron transport. In addition, hepcidin was initially identified as liver-expressed antimicrobial peptide (LEAP-1) due to its intrinsic antimicrobial activity and it has been proposed that hepcidin contributes to the innate defense system $[66,67]$. Interestingly, airway epithelial cells express hepcidin in response to interferon- $\gamma$, likely providing a direct protective mechanism against microbial growth [68]. These findings indicate two essential roles of hepcidin: a systemic irondependent interaction with FPN to maintain balance between nutrition and bacterial and viral pathogenicity in lung tissue as well as the body and an iron-independent, direct antimicrobial activity [31].

There is emerging recognition of the role siderocalin plays in iron metabolism. Also known as neutrophil-gelatinase-associated lipocalin or lipocalin-2, it is produced by neutrophil granules and in epithelial cells in response to inflammation. Siderocalin interferes with bacterial iron acquisition to inhibit growth [69] and transports $\mathrm{Fe}^{3+}$ in the blood in a complex with endogenous catechol or siderophores secreted by invading pathogens [70]. Pneumonia induced by intratracheal instillation of E. coli is exacerbated in siderocalin-deficient mice [71]. Furthermore, infection with active pulmonary tuberculosis in patients appears to be inversely associated with serum levels of siderocalin [72].
Therefore, siderocalin appears to provide a substantial contribution to restriction of iron availability to pathogens and prevention of infection specifically in the lung.

\section{Lung injury and iron}

Altered iron metabolism is linked to many lung diseases [38,73-75]. Elevated iron concentrations in the lung are associated with increased risk of pulmonary injury [38,75-77]. Among many organs in the body, the lung may have the greatest susceptibility to metal-induced oxidative stress due to its unique anatomical role for massive oxygen exchange along with large blood supplies. For example, inhaled iron from occupational settings or sites contaminated by heavy metals may promote reactive oxygen species. Changes in oxygen availability, such as hypoxia and hyperoxia, also alter iron metabolism. Lung injury is characterized by severe hypoxemia, increased endothelial and epithelial permeability, increased cytokine levels in the lungs and neutrophilic alveolar infiltrates [78]. Both acute and chronic lung injury leads to disruption of iron homeostasis in the lung [38]. The relationships between various types of lung injury and the regulation of iron metabolism are discussed below.

Acute respiratory distress syndrome (ARDS) is a type of inflammatory lung injury followed by endothelial activation and disruption of capillary membrane resulting in protein leakage $[79,80]$. Superoxide and hydrogen peroxide participate in the etiology of ARDS combined with ability of iron to catalyze more toxic reactive oxygen species [81-84]. Hence, iron can exacerbate ARDS [85]. High serum ferritin is associated with the development of ARDS [73]. Ferritin stores iron, distributing between extracellular and intracellular spaces to play a detoxifying role (Table 1, Figure 1). When iron levels increase, ferritin also increases to sequester reactive iron and as an acute reactive protein, ferritin synthesis is elevated during the inflammatory response. Increased ferritin levels observed in ARDS may result from increased tissue damage and lysis [73]. Since chelatable low molecular weight iron in respiratory extracellular fluid becomes elevated in patients with ARDS compared to normal healthy volunteers, it has been proposed that the presence of pro-oxidant iron in lung epithelial fluid may contribute to susceptibility to oxidative damage [28]. Lavage fluid of ARDS patients has elevated levels of total and nonheme iron as well as cellular content of Tf, ferritin and Lf [86]. This indicates impaired pulmonary homeostasis of iron in ARDS, although it is unclear whether this is due to general increase in membrane permeability or altered iron metabolism.

Pulmonary alveolar proteinosis (PAP) is characterized by abnormal accumulation of protein-rich surfactant in the lung and impaired pulmonary functions $[87,88]$. Patients with primary or idiopathic PAP show increased levels of iron, Tf, TfR, Lf and ferritin in lung lavage fluids, while the concentrations of antioxidants such as ascorbate and glutathione are reduced [74]. Moreover, intracellular concentrations of iron and ferritin are also elevated, suggesting metal-catalyzed oxidative stress [74]. It has been proposed that lower iron saturation of Tf decreases iron-mediated oxidative stress and rescues respiratory failure $[89,90]$. Secondary PAP can accompany infection, particle exposure and malignancies [38], most of which are associated with altered iron homeostasis. Together, a remarkable relationship between PAP and iron metabolism exists.

Smokers, whether they have bronchitis or not, display elevated iron levels in the lung [91], presumably due to formation of iron complexes by particulate matter in cigarette smoke [38]. Patients with cystic fibrosis also have elevated levels of iron and iron-related proteins in 
fibrosis also have elevated levels of iron and iron-related proteins in the lavage fluid and sputum compared with normal humans or patients with chronic obstructive pulmonary disease [92,93]. The elevated iron levels in cystic fibrosis are higher than those found in smokers [93] and are associated with increased inflammatory cytokines [92], indicating the significant role of iron in promoting oxidative injury in the lung [92]. Iron also modifies oxidative injury with ischemia/ reperfusion in the lung since released chelatable free iron promotes tissue oxidation during reperfusion [75]. This notion is supported by the result where desferrioxamine, an iron chelator, has been shown to partially protect against ischemic lung injury induced by reperfusion [94]. Lung transplantation is also associated with iron accumulation in the lung and increased levels of transferrin and its receptor, lactoferrin and ferritin, while systemic iron levels are unchanged [95,96]. These findings further suggest metal-induced damage via oxidative stress in the lung and implies a potential benefit of local chelation therapy to deplete iron from the lung [96].

\section{Implications and Applications}

It is now well recognized that the body has highly coordinated protective mechanisms from a variety of insults, such as pathogens, inflammation and oxidative stress by mobilizing or sequestering iron. Despite wide prevalence of lung injury and diseases that are associated with iron, there are few successful therapeutic advancements. Conventional methods to reduce iron burden in the body include dietary restriction, chelators and phlebotomy [38,97,98]. While still effective, these "passive or non-selective" interventions have considerable drawbacks such as systemic nutritional deficiency and severe adverse effects. These problems could be circumvented by "active or selective" therapies such as specific modulation of iron transporters, FPN and DMT1. For example, inhibitors of these transporters [99-101] might help decrease iron-associated cellular damage. Local or regional administration like inhalation of apotransferrin or other iron-chelating agents appear to be promising tools without perturbation of systemic iron homeostasis. Further study is clearly warranted to elucidate the benefits and risks of these potential therapeutic treatments in affecting changes in iron metabolism in lung injury and inflammation.

\section{Acknowledgement}

This work was supported by NIH grants K99 ES17781 (to J.K.) and R01 ES014638 (to M.W.-R)

\section{References}

1. Cheng Z, Li Y (2007) What is responsible for the initiating chemistry of ironmediated lipid peroxidation: an update. Chem Rev 107: 748-766.

2. Beard J (2003) Iron deficiency alters brain development and functioning. J Nutr 133: $1468 \mathrm{~S}-1472 \mathrm{~S}$

3. Lozoff B, Jimenez E, Wolf AW (1991) Long-term developmental outcome of infants with iron deficiency. N Engl J Med 325: 687-694.

4. Kwik-Uribe CL, Golub MS, Keen CL (2000) Chronic marginal iron intakes during early development in mice alter brain iron concentrations and behavior despite postnatal iron supplementation. J Nutr 130: 2040-2048.

5. Li Y, Kim J, Buckett PD, Böhlke M, Maher TJ, et al. (2011) Severe post-nata iron deficiency alters emotional behavior and dopamine levels in the prefrontal cortex of young male rats. J Nutr 141: 2133-2138.

6. Andrews NC, Schmidt PJ (2007) Iron homeostasis. Annu Rev Physiol 69: 6985.

7. Nemeth E, Ganz T (2006) Regulation of iron metabolism by hepcidin. Annu Rev Nutr 26: 323-342.

8. Wessling-Resnick M (2010) Iron homeostasis and the inflammatory response. Annu Rev Nutr 30: 105-122.
9. Gunshin H, Mackenzie B, Berger UV, Gunshin Y, Romero MF, et al. (1997) Cloning and characterization of a mammalian proton-coupled metal-ion transporter. Nature 388: 482-488.

10. Fleming MD, Romano MA, Su MA, Garrick LM, Garrick MD, et al. (1998) Nramp2 is mutated in the anemic Belgrade (b) rat: evidence of a role for Nramp2 in endosomal iron transport. Proc Natl Acad Sci U S A 95: 1148-1153.

11. McKie AT, Barrow D, Latunde-Dada GO, Rolfs A, Sager G, et al. (2001) An iron-regulated ferric reductase associated with the absorption of dietary iron. Science 291: 1755-1759.

12. Shayeghi M, Latunde-Dada GO, Oakhill JS, Laftah AH, Takeuchi K, et al. (2005) Identification of an intestinal heme transporter. Cell 122: 789-801.

13. Rajagopal A, Rao AU, Amigo J, Tian M, Upadhyay SK, et al. (2008) Haem homeostasis is regulated by the conserved and concerted functions of HRG-1 proteins. Nature 453: 1127-1131.

14. Abboud S, Haile DJ (2000) A novel mammalian iron-regulated protein involved in intracellular iron metabolism. J Biol Chem 275: 19906-19912.

15. McKie AT, Marciani P, Rolfs A, Brennan K, Wehr K, et al. (2000) A nove duodenal iron-regulated transporter, IREG1, implicated in the basolateral transfer of iron to the circulation. Mol Cell 5: 299-309.

16. Vulpe CD, Kuo YM, Murphy TL, Cowley L, Askwith C, et al. (1999) Hephaestin a ceruloplasmin homologue implicated in intestinal iron transport, is defective in the sla mouse. Nat Genet 21: 195-199.

17. Fleming MD, Trenor CC, Su MA, Foernzler D, Beier DR, et al. (1997) Microcytic anaemia mice have a mutation in Nramp2, a candidate iron transporter gene. Nat Genet 16: 383-386.

18. Gitlin D, Cruchaud A (1962) On the kinetics of iron absorption in mice. J Clin Invest $41: 344-350$

19. Mackenzie B, Takanaga H, Hubert N, Rolfs A, Hediger MA (2007) Functional properties of multiple isoforms of human divalent metal-ion transporter (DMT1). Biochem J 403: 59-69.

20. Donovan A, Roy CN, Andrews NC (2006) The ins and outs of iron homeostasis Physiology (Bethesda) 21: 115-123.

21. Nicolas G, Bennoun M, Devaux I, Beaumont C, Grandchamp B, et al. (2001) Lack of hepcidin gene expression and severe tissue iron overload in upstream stimulatory factor 2 (USF2) knockout mice. Proc Natl Acad Sci U S A 98: 87808785.

22. Pigeon C, llyin G, Courselaud B, Leroyer P, Turlin B, et al. (2001) A new mouse liver-specific gene, encoding a protein homologous to human antimicrobia peptide hepcidin, is overexpressed during iron overload. J Biol Chem 276 : 7811-7819.

23. Nemeth E, Tuttle MS, Powelson J, Vaughn MB, Donovan A, et al. (2004) Hepcidin regulates cellular iron efflux by binding to ferroportin and inducing its internalization. Science 306: 2090-2093.

24. Brasse-Lagnel C, Karim Z, Letteron P, Bekri S, Bado A, et al. (2011) Intestinal DMT1 cotransporter is down-regulated by hepcidin via proteasome internalization and degradation. Gastroenterology 140: 1261-1271.

25. Heilig EA, Thompson KJ, Molina RM, Ivanov AR, Brain JD, et al. (2006) Manganese and iron transport across pulmonary epithelium. Am J Physiol Lung Cell Mol Physiol 290: L1247-1259.

26. Heilig E, Molina R, Donaghey T, Brain JD, Wessling-Resnick M (2005) Pharmacokinetics of pulmonary manganese absorption: evidence for increased susceptibility to manganese loading in iron-deficient rats. Am J Physiol Lung Cell Mol Physiol 288: L887-893

27. Thompson K, Molina R, Donaghey T, Brain JD, Wessling-Resnick M (2006) The influence of high iron diet on rat lung manganese absorption. Toxicol App Pharmacol 210: 17-23.

28. Gutteridge JM, Mumby S, Quinlan GJ, Chung KF, Evans TW (1996) Prooxidant iron is present in human pulmonary epithelial lining fluid: implications for oxidative stress in the lung. Biochem Biophys Res Commun 220: 1024 1027

29. Schroeder WH, Dobson M, Kane DM, Johnson ND (1987) Toxic trace element associated with airborne particulate matter: a review. JAPCA 37: 1267-1285.

30. Turi JL, Yang F, Garrick MD, Piantadosi CA, Ghio AJ (2004) The iron cycle and oxidative stress in the lung. Free Radic Biol Med 36: 850-857. 
Citation: Kim J, Wessling-Resnick M (2012) The Role of Iron Metabolism in Lung Inflammation and Injury. J Aller Ther S4:004 doi:10.4172/2155-6121. S4-004

31. Johnson EE, Wessling-Resnick M (2011) Iron metabolism and the innate immune response to infection. Microbes Infect 14: 207-216

32. Kochan I (1973) The role of iron in bacterial infections, with special consideration of host-tubercle bacillus interaction. Curr Top Microbiol Immunol 60: 1-30.

33. Lounis N, Truffot-Pernot C, Grosset J, Gordeuk VR, Boelaert JR (2001) Iron and Mycobacterium tuberculosis infection. J Clin Virol 20: 123-126.

34. Murray MJ, Murray AB, Murray MB, Murray CJ (1978) The adverse effect of iron repletion on the course of certain infections. Br Med J 2: 1113-1115.

35. Ratledge C (2004) Iron, mycobacteria and tuberculosis. Tuberculosis (Edinb) 84:110-130.

36. Gangaidzo IT, Moyo VM, Mvundura E, Aggrey G, Murphree NL, et al. (2001) Association of pulmonary tuberculosis with increased dietary iron. $J$ Infect Dis 184: 936-939.

37. Moalem S, Weinberg ED, Percy ME (2004) Hemochromatosis and the enigma of misplaced iron: implications for infectious disease and survival. Biometals 17: $135-139$

38. Ghio AJ (2009) Disruption of iron homeostasis and lung disease. Biochim Biophys Acta 1790: 731-739.

39. Byrd TF, Horwitz MA (1989) Interferon gamma-activated human monocytes downregulate transferrin receptors and inhibit the intracellular multiplication of Legionella pneumophila by limiting the availability of iron. J Clin Invest 83 : $1457-1465$.

40. Byrd TF, Horwitz MA (1993) Regulation of transferrin receptor expression and ferritin content in human mononuclear phagocytes. Coordinate upregulation by iron transferrin and downregulation by interferon gamma. J Clin Invest 91 : 969-976.

41. Clemens DL, Horwitz MA (1996) The Mycobacterium tuberculosis phagosome interacts with early endosomes and is accessible to exogenously administered transferrin. J Exp Med 184: 1349-1355.

42. Halaas O, Steigedal M, Haug M, Awuh JA, Ryan L, et al. (2010) Intracellular Mycobacterium avium intersect transferrin in the Rab11(+) recycling endocytic pathway and avoid lipocalin 2 trafficking to the lysosomal pathway. J Infect Dis 201: 783-792.

43. Schaible UE, Collins HL, Priem F, Kaufmann SH (2002) Correction of the iron overload defect in beta-2-microglobulin knockout mice by lactoferrin abolishes their increased susceptibility to tuberculosis. J Exp Med 196: 1507-1513.

44. Britigan BE, Hayek MB, Doebbeling BN, Fick RB, (1993) Transferrin and lactoferrin undergo proteolytic cleavage in the Pseudomonas aeruginosainfected lungs of patients with cystic fibrosis. Infect Immun 61: 5049-5055.

45. Singh PK, Parsek MR, Greenberg EP, Welsh MJ (2002) A component of innate immunity prevents bacterial biofilm development. Nature 417: 552-555.

46. Ward PP, Mendoza-Meneses M, Park PW, Conneely OM (2008) Stimulusdependent impairment of the neutrophil oxidative burst response in lactoferrindeficient mice. Am J Pathol 172: 1019-1029.

47. Cellier MF, Courville P, Campion C (2007) Nramp1 phagocyte intracellular metal withdrawal defense. Microbes Infect 9: 1662-1670.

48. Forbes JR, Gros P (2001) Divalent-metal transport by NRAMP proteins at the interface of host-pathogen interactions. Trends Microbiol 9: 397-403.

49. Valdez Y, Grassl GA, Guttman JA, Coburn B, Gros P, et al. (2009) Nramp1 drives an accelerated inflammatory response during Salmonella-induced colitis in mice. Cell Microbiol 11: 351-362.

50. Nairz M, Fritsche G, Brunner P, Talasz H, Hantke K, et al. (2008) Interferongamma limits the availability of iron for intramacrophage Salmonella typhimurium. Eur J Immunol 38: 1923-1936.

51. Nairz M, Theurl I, Ludwiczek S, Theurl M, Mair SM, et al. (2007) The coordinated regulation of iron homeostasis in murine macrophages limits the availability of iron for intracellular Salmonella typhimurium. Cell Microbiol 9 : 2126-2140.

52. Nairz M, Fritsche G, Crouch ML, Barton HC, Fang FC, et al. (2009) Slc11a1 limits intracellular growth of Salmonella enterica sv. Typhimurium by promoting macrophage immune effector functions and impairing bacterial iron acquisition. Cell Microbiol 11: 1365-1381.

53. Brain JD, Heilig E, Donaghey TC, Knutson MD, Wessling-Resnick M, et al
(2006) Effects of iron status on transpulmonary transport and tissue distribution of $\mathrm{Mn}$ and Fe. Am J Respir Cell Mol Biol 34: 330-337.

54. Thompson K, Molina RM, Donaghey T, Schwob JE, Brain JD, et al. (2007) Olfactory uptake of manganese requires DMT1 and is enhanced by anemia. FASEB J 21: 223-230.

55. Dallman PR (1987) Iron deficiency and the immune response. Am J Clin Nutr 46: 329-334

56. Turi JL, Wang X, McKie AT, Nozik-Grayck E, Mamo LB, et al. (2006) Duodena cytochrome b: a novel ferrireductase in airway epithelial cells. Am J Physio Lung Cell Mol Physiol 291: L272-280.

57. Wang X, Garrick MD, Yang F, Dailey LA, Piantadosi CA, et al. (2005) TNF IFN-gamma, and endotoxin increase expression of DMT1 in bronchial epithelial cells. Am J Physiol Lung Cell Mol Physiol 289: L24-33.

58. Wang X, Wu Y, Stonehuerner JG, Dailey LA, Richards JD, et al. (2006) Oxidant generation promotes iron sequestration in BEAS-2B cells exposed to asbestos. Am J Respir Cell Mol Biol 34: 286-292.

59. Ghio AJ, Piantadosi CA, Wang X, Dailey LA, Stonehuerner JD, et al. (2005) Divalent metal transporter-1 decreases metal-related injury in the lung. Am J Physiol Lung Cell Mol Physiol 289: L460-467.

60. Kim J, Molina RM, Donaghey TC, Buckett PD, Brain JD, et al. (2011) Influence of DMT1 and iron status on inflammatory responses in the lung. Am J Physiol Lung Cell Mol Physiol 300: L659-665.

61. Ghio AJ, Turi JL, Madden MC, Dailey LA, Richards JD, et al. (2007) Lung injury after ozone exposure is iron dependent. Am J Physiol Lung Cell Mol Physiol 292: L134-143.

62. Khan FA, Fisher MA, Khakoo RA (2007) Association of hemochromatosis with infectious diseases: expanding spectrum. Int J Infect Dis 11: 482-487.

63. Olakanmi O, Schlesinger LS, Britigan BE (2007) Hereditary hemochromatosis results in decreased iron acquisition and growth by Mycobacterium tuberculosis within human macrophages. J Leukoc Biol 81: 195-204.

64. Chlosta S, Fishman DS, Harrington L, Johnson EE, Knutson MD, et al. (2006) The iron efflux protein ferroportin regulates the intracellular growth of Salmonella enterica. Infect Immun 74: 3065-3067.

65. Paradkar PN, De Domenico I, Durchfort N, Zohn I, Kaplan J, et al. (2008) Iron depletion limits intracellular bacterial growth in macrophages. Blood 112: 866874.

66. Park CH, Valore EV, Waring AJ, Ganz T (2001) Hepcidin, a urinary antimicrobial peptide synthesized in the liver. J Biol Chem 276: 7806-7810.

67. Krause A, Neitz S, Mägert HJ, Schulz A, Forssmann WG, et al. (2000) LEAP-1, a novel highly disulfide-bonded human peptide, exhibits antimicrobial activity. FEBS Lett 480: 147-150.

68. Frazier MD, Mamo LB, Ghio AJ, Turi JL (2011) Hepcidin expression in human airway epithelial cells is regulated by interferon-gamma. Respir Res 12: 100

69. Goetz DH, Holmes MA, Borregaard N, Bluhm ME, Raymond KN, et al. (2002 The neutrophil lipocalin NGAL is a bacteriostatic agent that interferes with siderophore-mediated iron acquisition. Mol Cell 10: 1033-1043.

70. Bao G, Clifton M, Hoette TM, Mori K, Deng SX, et al. (2010) Iron traffics in circulation bound to a siderocalin (Ngal)-catechol complex. Nat Chem Biol 6 : 602-609.

71. Wu H, Santoni-Rugiu E, Ralfkiaer E, Porse BT, Moser C, et al. (2010) Lipocalin 2 is protective against $\mathrm{E}$. coli pneumonia. Respir Res 11: 96.

72. Martineau AR, Newton SM, Wilkinson KA, Kampmann B, Hall BM, et al. (2007) Neutrophil-mediated innate immune resistance to mycobacteria. J Clin Invest 117: 1988-1994.

73. Sharkey RA, Donnelly SC, Connelly KG, Robertson CE, Haslett C, et al. (1999) Initial serum ferritin levels in patients with multiple trauma and the subsequent development of acute respiratory distress syndrome. Am J Respir Crit Care Med 159: 1506-1509.

74. Ghio AJ, Stonehuerner JG, Richards JH, Crissman KM, Roggli VL, et al. (2008) Iron homeostasis and oxidative stress in idiopathic pulmonary alveolar proteinosis: a case-control study. Respir Res 9: 10.

75. Zhao G, Ayene IS, Fisher AB (1997) Role of iron in ischemia-reperfusion oxidative injury of rat lungs. Am J Respir Cell Mol Biol 16: 293-299. 
Citation: Kim J, Wessling-Resnick M (2012) The Role of Iron Metabolism in Lung Inflammation and Injury. J Aller Ther S4:004 doi:10.4172/2155-6121. S4-004

76. Ghio AJ, Churg A, Roggli VL (2004) Ferruginous bodies: implications in the mechanism of fiber and particle toxicity. Toxicol Pathol 32: 643-649.

77. Burger RM, Peisach J, Horwitz SB (1981) Activated bleomycin. A transient complex of drug, iron, and oxygen that degrades DNA. J Biol Chem 256: 1163611644.

78. Matute-Bello G, Frevert CW, Martin TR (2008) Animal models of acute lung injury. Am J Physiol Lung Cell Mol Physiol 295: L379-399.

79. Ashbaugh DG, Bigelow DB, Petty TL, Levine BE (1967) Acute respiratory distress in adults. Lancet 2: 319-323.

80. Ware LB, Matthay MA (2000) The acute respiratory distress syndrome. N Engl J Med 342: 1334-1349.

81. Repine JE (1992) Scientific perspectives on adult respiratory distress syndrome. Lancet 339: 466-469.

82. Brigham KL (1990) Oxidant stress and adult respiratory distress syndrome. Eur Respir J Suppl 11: 482s-484s.

83. Seibert AF, Taylor AE, Bass JB, Haynes J (1991) Hemoglobin potentiates oxidant injury in isolated rat lungs. Am J Physiol 260: H1980-1984.

84. Sullivan KM, Saunders JR (1989) Nucleotide sequence and genetic organization of the NgoPII restriction-modification system of Neisseria gonorrhoeae. Mo Gen Genet 216: 380-387.

85. Connelly KG, Moss M, Parsons PE, Moore EE, Moore FA, et al. (1997) Serum ferritin as a predictor of the acute respiratory distress syndrome. Am J Respir Crit Care Med 155: 21-25.

86. Ghio AJ, Carter JD, Richards JH, Richer LD, Grissom CK, et al. (2003) Iron and iron-related proteins in the lower respiratory tract of patients with acute respiratory distress syndrome. Crit Care Med 31: 395-400.

87. Rosen SH, Castleman B, Liebow AA (1958) Pulmonary alveolar proteinosis. N Engl J Med 258: 1123-1142.

88. Shimizu Y, Matsuzaki S, Dobashi K, Yanagitani N, Satoh T, et al. (2011) Elemental analysis of lung tissue particles and intracellular iron content of alveolar macrophages in pulmonary alveolar proteinosis. Respir Res 12: 88.

89. Hallman M, Sarnesto A, Bry K (1994) Interaction of transferrin saturated with iron with lung surfactant in respiratory failure. J Appl Physiol 77: 757-766.

90. Hallman M, Chundu V, Barsotti M, Bry K (1996) Transferrin modifies surfactant responsiveness in acute respiratory failure: role of iron-free transferrin as an antioxidant. Pediatr Pulmonol 22: 14-22.

91. Thompson AB, Bohling T, Heires A, Linder J, Rennard SI (1991) Lower respiratory tract iron burden is increased in association with cigarette smoking J Lab Clin Med 117: 493-499.

92. Stites SW, Plautz MW, Bailey K, O'Brien-Ladner AR, Wesselius LJ (1999) Increased concentrations of iron and isoferritins in the lower respiratory tract of patients with stable cystic fibrosis. Am J Respir Crit Care Med 160: 796-801.

93. Reid DW, Lam QT, Schneider H, Walters EH (2004) Airway iron and ironregulatory cytokines in cystic fibrosis. Eur Respir J 24: 286-291.

94. Ayene IS, al-Mehdi AB, Fisher AB (1993) Inhibition of lung tissue oxidation during ischemia/reperfusion by 2-mercaptopropionylglycine. Arch Biochem Biophys 303: 307-312.

95. Baz MA, Ghio AJ, Roggli VL, Tapson VF, Piantadosi CA (1997) Iron accumulation in lung allografts after transplantation. Chest 112: 435-439.

96. Pugh C, Hathwar V, Richards JH, Stonehuerner J, Ghio AJ (2005) Disruption of iron homeostasis in the lungs of transplant patients. J Heart Lung Transplant 24: $1821-1827$.

97. Lagan AL, Melley DD, Evans TW, Quinlan GJ (2008) Pathogenesis of the systemic inflammatory syndrome and acute lung injury: role of iron mobilization and decompartmentalization. Am J Physiol Lung Cell Mol Physiol 294: L161174

98. Reid DW, Anderson GJ, Lamont IL (2009) Role of lung iron in determining the bacterial and host struggle in cystic fibrosis. Am J Physiol Lung Cell Mol Physio 297: L795-802.

99. Preza GC, Ruchala P, Pinon R, Ramos E, Qiao B, et al. (2011) Minihepcidins are rationally designed small peptides that mimic hepcidin activity in mice and may be useful for the treatment of iron overload. J Clin Invest 121: 4880-4888.

100. De Domenico I, Lo E, Yang B, Korolnek T, Hamza I, et al. (2011) The role of ubiquitination in hepcidin-independent and hepcidin-dependent degradation of ferroportin. Cell Metab 14: 635-646.

101. Wetli HA, Buckett PD, Wessling-Resnick M (2006) Small-molecule screening identifies the selanazal drug ebselen as a potent inhibitor of DMT1-mediated iron uptake. Chem Biol 13: 965-972.
This article was originally published in a special issue, Lung Disorders/Injury handled by Editor(s). Dr. Yutong Zhao, University of Pittsburgh, USA 